\title{
New Antarctic clawed lobster species (Crustacea: Decapoda: Nephropidae) from the Upper Cretaceous of James Ross Island
}

\author{
Allysson P. Pinheiro, ${ }^{1,2}$ (1) Antônio Álamo Feitosa Saraiva, ${ }^{2,3}$ (1) William Santana, ${ }^{1,2}$ (1) Juliana Manso Sayão, ${ }^{4}$ (]) \\ Rodrigo Giesta Figueiredo, ${ }^{5}$ (1) Taissa Rodrigues, ${ }^{6}$ (1) Luiz Carlos Weinschütz, ${ }^{7}$ Luiza Corral Martins de \\ Oliveira Ponciano ${ }^{8}$ (1) \& Alexander Wilhelm Armin Kellner ${ }^{9}$ (1) \\ 'Laboratório de Crustáceos do Semiárido, Universidade Regional do Cariri, Crato, CE, Brazil; \\ 2Laboratory of Systematic Zoology, Pró-Reitoria de Pesquisa e Pós-Graduação, Universidade do Sagrado Coração, Bauru, SP, Brazil; \\ ${ }^{3}$ Laboratório de Paleontologia, Universidade Regional do Cariri, Crato, CE, Brazil; \\ ${ }^{4}$ Laboratório de Paleobiologia e Paleogeografia Antártica, Museu Nacional/Universidade Federal do Rio de Janeiro, RJ, Brazil; \\ ${ }^{5}$ Departamento de Biologia, Universidade Federal do Espírito Santo, Alegre, ES, Brazil; \\ ‘Laboratório de Paleontologia, Departamento de Ciências Biológicas, Centro de Ciências Humanas e Naturais, Universidade Federal do Espírito Santo, \\ Vitória, ES, Brazil; \\ ${ }^{7}$ Centro Paleontológico da Universidade do Contestado, Universidade do Contestado, Mafra, SC, Brazil; \\ ${ }^{8}$ Laboratório de Tafonomia e Paleoecologia Aplicadas, Departamento de Ciências Naturais, Universidade Federal do Estado do Rio de Janeiro, Brazil; \\ 'Laboratory of Systematics and Taphonomy of Fossil Vertebrates, Departamento de Geologia e Paleontologia, Museu Nacional/Universidade Federal do \\ Rio de Janeiro, Rio de Janeiro, RJ, Brazil
}

\begin{abstract}
A new species of nephropid lobster, Hoploparia echinata sp. nov., from the James Ross Island in the Antarctic Peninsula is here described and illustrated. The material was collected in the Santa Marta Formation (SantonianCampanian), the basal unit of the Marambio Group, Larsen Basin, located in the western portion of the Antarctic Peninsula. Hoploparia echinata sp. nov. can easily be differentiated from its congeners by the presence of distinct short spines on dorsal and ventral margins on the third maxillipeds, merus of the chelipeds and pereopods; these are the characters not described in other Hoploparia species so far.
\end{abstract}

\section{Keywords}

Astacidea; Hoploparia; Metanephrops; Nephropoidea; Marambio Group

\section{Correspondence}

William Santana, Laboratory of Systematic Zoology, Pró-Reitoria de Pesquisa e PósGraduação, Universidade do Sagrado

Coração, Rua Irmã Arminda, 10-50, Jd. Brasil, 17011-160, Bauru, SP, Brazil.

E-mail:willsantana@gmail.com

\begin{abstract}
Abbreviations
PALEOANTAR: Paleobiology and Paleogeography of South Gondwana: Interrelationships between Antarctica and South America (research project); PROANTAR: Programa Antártico Brasileiro (Brazilian Antarctic Programme); USNM: National Museum of Natural History, Smithsonian Institution, Washington D.C.; MN: Museu Nacional (Rio de Janeiro); MN-I: Palaeoinvertebrate collection, Museu Nacional (Rio de Janeiro); P1: cheliped (the claw-bearing pair of legs in decapod crustaceans); P2-P5: pereopods 2-5 (pairs of the walking limbs of a crustacean); UFRJ: Federal University of Rio de Janeiro
\end{abstract}

Zoobank publication registry

LSID urn:Isid:zoobank.org:pub:216FFB2A-DC53-4225-976B-60C65EB46BEB

\section{Introduction}

Antarctica plays a very important role in understanding faunal groups with Gondwanan origin (Crame 1989; Clarke et al. 2004). However, on the account of the continent's inhospitable conditions, its remoteness and the high cost of operations, Antarctica's fossil record is generally scarce compared to deposits in other continents (e.g., Kellner 1996; Feldmann \& Schweitzer 2017; Kellner et al. 2019; Zhang et al. 2019). The James Ross Basin, in the Antarctic Peninsula, has one of the best-preserved and highly diverse fossil assemblages of the continent (Feldmann 1990; Feldmann et al. 1993). In the stratigraphic context of this basin, the Santa Marta Formation (Santonian-Campanian) has abundant records of decapods, especially nephropids (Feldmann \& Tshudy 1989; Feldmann et al. 1993). Among the Nephropidae, the genus Hoploparia McCoy, 1849 is the best-known fossil group, with 67 species described worldwide, ranging from the Lower Cretaceous (Valanginian) to the Miocene (Tshudy \& Sorhannus 2003; Schweitzer et al. 2010). Although well represented in the fossil record, the genus is considered to be a "wastebasket taxon", difficult to characterize (Tshudy \& Sorhannus 2003). Despite the high diversity of the genus, Hoploparia stokesi (Weller, 1913), from the Lower Cretaceous to the Paleocene, and H. gazdzickii 
Feldmann \& Crame, 1998 from the Early Miocene are the only known species in the Antarctic region, with several specimens collected on Seymour, Vega, King George, Mumps and Cockburn islands (Ball 1960; Feldmann \& Tshudy 1987; Feldmann \& Crame 1998; El-Shazly 2015).

PALEOANTAR fieldwork at Santa Marta Cove, James Ross Island, during the Antarctic summer of 2015/16 (supported by PROANTAR) revealed a great number of fossil specimens, including decapods. Two specimens collected in the horizons of the Santa Marta Formation exhibit some characteristics previously unknown in other Hoploparia species, and a new taxon, H. echinata sp. nov., is proposed.

\section{Geological settings}

The Marambio Group, Larsen Basin, is located in the western portion of the Antarctic Peninsula, on James Ross Island (Fig. 1). The Larsen Basin, according to Macdonald et al. (1988), is divided into two sub-basins: South and James Ross. The James Ross Sub-basin originated during the breakdown of Gondwana with the deposition of a Meso-Cenozoic sedimentary sequence in a retroarc basin (Hathway 2000). It is considered one of the thickest and most complete volcano-sedimentary sequences deposited in the Cretaceous-Paleogene of the Southern Hemisphere (Crame et al. 1996) and is divided
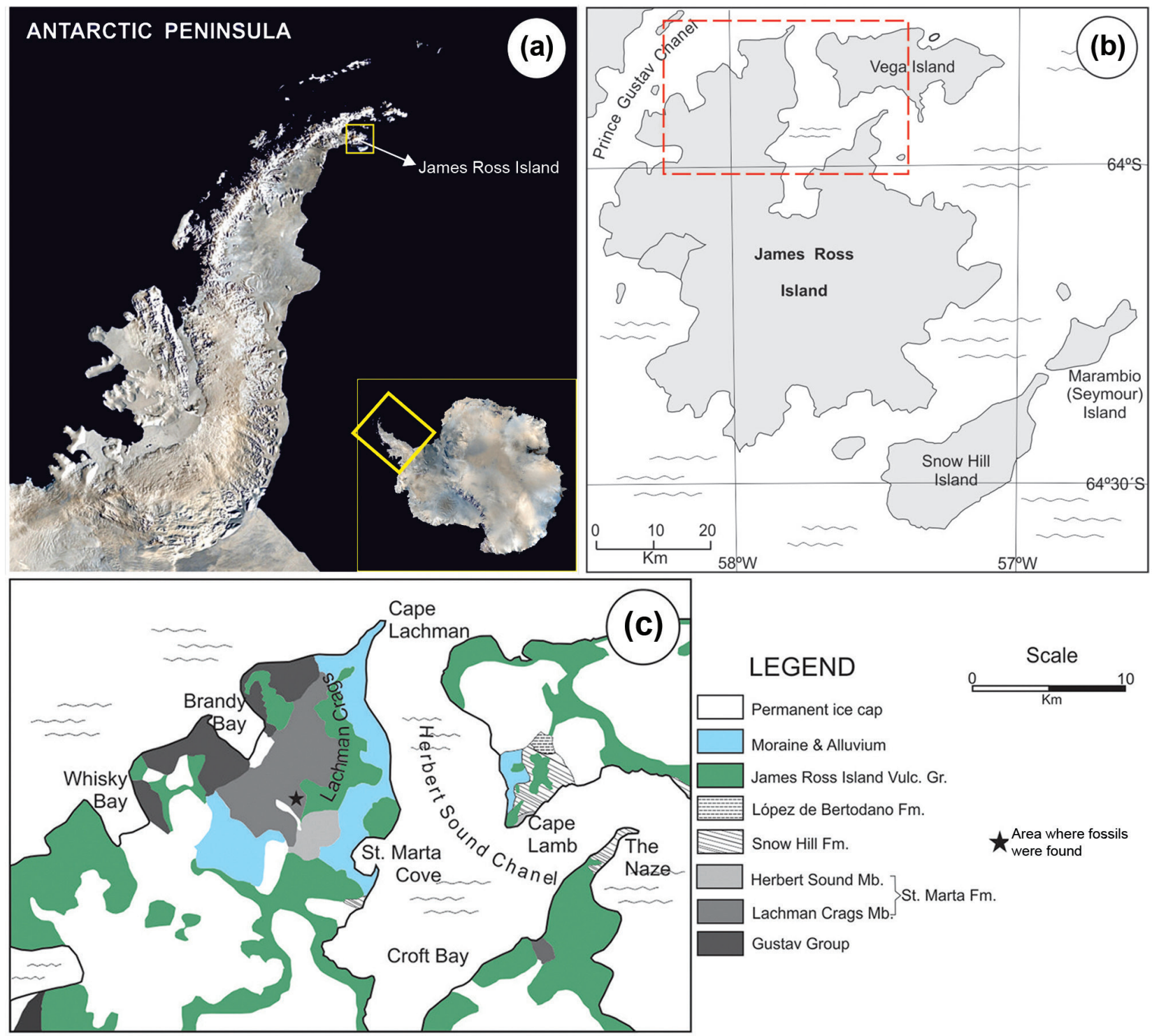

Fig. 1 Map of fossil location and occurrence (a) Location of the Antarctic Peninsula indicating the James Ross Island. (b) Detail of the James Ross and Vega islands; red square indicates the area where fieldwork was carried out. (c) Geological map of the prospected area, showing where fossils were found. 
lithostratigraphically into the Nodenskjöld Formation and the Gustav and Marambio groups (Hathway 2000; Hathway \& Riding 2001; Riding \& Crame 2002).

The Marambio Group crops out in portions of the James Ross, Vega, Humps, Snow Hill, Seymour and Cockburn islands. These deposits represent a progradant system composed of a variety of sandstones, siltstones and mudstones and coquina levels, which were deposited under storm conditions at the internal to external platform (Crame et al. 1991; Crame et al. 2004). The Marambio Group is divided into the Santa Marta, Snow Hill Island, Lopez de Bertodano and Sobral formations (Fig. 2).

The Santa Marta Formation (Santonian-Campanian) is the basal unit of the Marambio Group. It is over $900 \mathrm{~m}$ thick and consists of a sequence of intercalated sandstones, siltstones and volcanic tuffs (Olivero 2012), interpreted as a sequence of volcanoclastic deposits formed in a deltaic environment (Scasso et al. 1991; Olivero 2012). In the north-western portion of James Ross Island, the

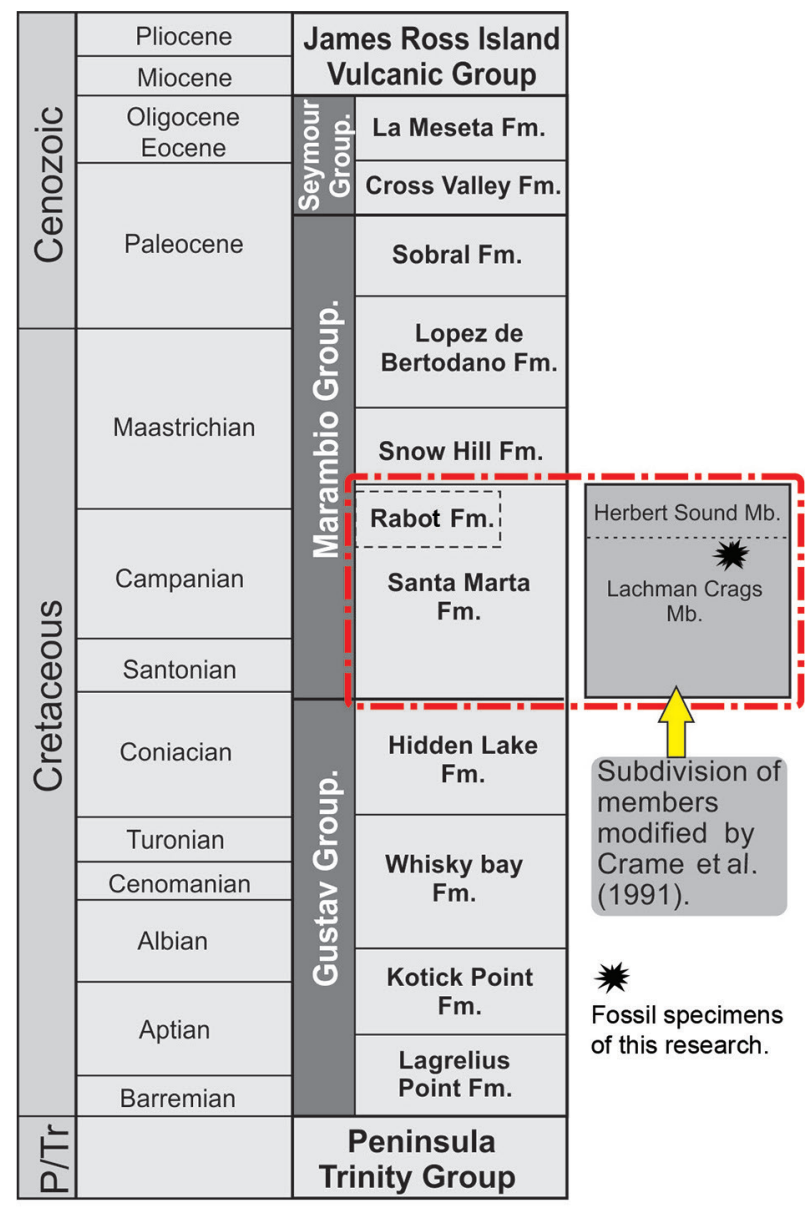

Fig. 2 Stratigraphic chart of James Ross Sub-basin (modified from Olivero et al. 1986 and Marenssi et al. 2001).
Santa Marta Formation is divided into the Lachman Crags and the Herbert Sound members (Crame et al. 1991).

The basal Lachman Crags Member (late Coniacian to late Campanian) has a thickness of approximately $850 \mathrm{~m}$ and consists of rare conglomerate clays, siltstones and sandstones that were deposited in a shallow marine environment (Crame et al. 1991; Carvalho et al. 2013). The upper Herbert Sound Member (late Campanian to the early Maastrichtian [Crame et al. 1991]) is $250 \mathrm{~m}$ thick and consists of fine sandstone with cross-stratification and coquina levels (Crame et al. 1991; Olivero et al. 1986; Crame et al. 1999; Olivero \& Medina 2000).

The fossil specimens studied here were collected in layers that correspond to the upper portion of the Lachman Crags Member, which is the sole stratigraphic unit in the immediate area where the specimens were collected. They were found in concretions that were scattered on the surface and lack any feature indicating significant transportation. Such preservation is rather common in fossils found at James Ross Island (e.g., Kellner et al. 2011).

\section{Material and methods}

The descriptive terminology mostly follows that used by Holthuis (1974) and Tshudy \& Sorhannus (2003). Descriptions, drawings and photographs were made using a Nikon SMZ 745T stereomicroscope equipped with a camera lucida and a Leica EZ4 W, both with digital cameras attached. The paratype was coated with Paraloid B-72 and ultraviolet lights were used to photograph the holotype.

Information provided for the comparative material has been retrieved from the labels of the material examined at the USNM, which may be divergent from what is presented in the original descriptions of $H$. stokesi (Weller, 1903) and Metanephrops jenkinsi Feldmann, 1989. For a list of all the examined material, see Table 1.

\section{Systematic palaeontology}

Order Decapoda Latreille, 1802

Infraorder Astacidea Latreille, 1802

Remarks: The Astacidea are easily distinguished from the other lobsters by the presence of a generally large, true chelae (i.e., with the dactylus opposed to an extension of the propodus on most of its length) on the first pair of pereopods, this being the largest and most robust pair (Holthuis 1991). Although not fully preserved in the new species, the first pereopod is the largest and more robust, with the merus and carpus fully preserved and the palm partially preserved proximally (Fig. 3). The palm 
Table 1 List of comparative material observed in the present study.

\begin{tabular}{|c|c|c|c|c|}
\hline $\begin{array}{l}\text { Species } \\
\text { catalogue no. }\end{array}$ & $\begin{array}{l}\text { Sampling site } \\
\text { (Antarctica) }^{\mathrm{a}}\end{array}$ & Geology ${ }^{b}$ & $\mathrm{Age}^{\mathrm{c}}$ & $\begin{array}{c}\text { Type } \\
\text { material }\end{array}$ \\
\hline \multicolumn{5}{|c|}{ Hoploparia stokesi (Weller, 1903) } \\
\hline USNM 410841 & SI & LBF, Unit 7 & $\mathrm{LCr}$ & Non-type \\
\hline USNM 410855 & SI & LBF, Unit 7 & $\mathrm{LCr}$ & Non-type \\
\hline USNM 458905 & SI & LBF, Unit 9 & $\mathrm{LCr}$ & Paratype \\
\hline USNM 458907 & SI & LBF, Unit 9 & $\mathrm{LCr}$ & Paratype \\
\hline USNM 410891 & SI & LBF, Unit 9 & $\mathrm{LCr}$ & Non-type \\
\hline USNM 458910 & SI & LBF, Unit 9 & $\mathrm{LCr}$ & Paratype \\
\hline USNM 458911 & SI & LBF, Unit 9 & $\mathrm{LCr}$ & Paratype \\
\hline USNM 458915 & $\mathrm{SI}$ & LBF, Unit 8 & $\mathrm{LCr}$ & Paratype \\
\hline USNM 458917 & SI & LBF, Unit 9 & $\mathrm{LCr}$ & Paratype \\
\hline USNM 458919 & SI & LBF, Unit 9 & $\mathrm{LCr}$ & Paratype \\
\hline USNM 410842 & SI & LBF, Unit 7 & $\mathrm{LCr}$ & Paratype \\
\hline USNM 410844 & SI & LBF, Unit 7 & $\mathrm{LCr}$ & Paratype \\
\hline USNM 410846 & SI & LBF, Unit 7 & $\mathrm{LCr}$ & Paratype \\
\hline USNM 410847 & SI & LBF, Unit 7 & $\mathrm{LCr}$ & Paratype \\
\hline USNM 410848 & SI & LBF, Unit 7 & $\mathrm{LCr}$ & Paratype \\
\hline USNM 410849 & SI & LBF, Unit 7 & $\mathrm{LCr}$ & Paratype \\
\hline USNM 410850 & $\mathrm{SI}$ & LBF, Unit 7 & $\mathrm{LCr}$ & Paratype \\
\hline USNM 410853 & SI & LBF, Unit 7 & $\mathrm{LCr}$ & Paratype \\
\hline USNM 410859 & SI & LBF, Unit 7 & $\mathrm{LCr}$ & Paratype \\
\hline USNM 410883 & SI & LBF, Unit 7 & $\mathrm{LCr}$ & Paratype \\
\hline USNM 430025 & SI & LBF, Unit 7-9 & $\mathrm{LCr}, \mathrm{LCa}$ & Non-type \\
\hline USNM 458920 & VIFIP & LBF & $\mathrm{LCr}$ & Non-type \\
\hline USNM 458904 & VIFIP & LBF & $\mathrm{LCr}$ & Non-type \\
\hline USNM 458912 & MI & $\mathrm{LBF}, \mathrm{CLM}$ & $\mathrm{LCr}$ & Non-type \\
\hline USNM 458914 & $\mathrm{Cl}$ & $\mathrm{LBF}, \mathrm{CLM}$ & $\mathrm{LCr}$ & Paratype \\
\hline \multicolumn{5}{|c|}{ Metanephrops jenkinsi Feldmann, 1989} \\
\hline USNM 424602 & SI & LBF, Unit 10 & $\mathrm{LCr}$ & Paratype \\
\hline USNM 424609 & SI & LBF, Unit 10 & $\mathrm{~Pa}$ & Paratype \\
\hline USNM 424614 & SI & SF, Unit 3 & $\mathrm{~Pa}$ & Paratype \\
\hline USNM 424600 & SI & LBF, Unit 10 & $\mathrm{~Pa}$ & Paratype \\
\hline USNM 424605 & SI & LBF, Unit 10 & $\mathrm{~Pa}$ & Paratype \\
\hline
\end{tabular}

aSeymour Island is abbreviated to SI; Vega Island, False Island Point to VIFIP; Mumps Island to MI; Cockburn Island to $\mathrm{Cl}$. ' Lopez de Bertodano Formation is abbreviated to LBF; Cape Lamb Member to CLM; Sobral Formation to SF. 'Late Cretaceous is abbreviated to LCr; Late Campanian to LCa; Paleocene to Pa.

is elongated, slightly inflated and with distinct tubercles sparsely distributed in all surfaces, common characteristics of several Astacidea, including Hoploparia. We therefore consider the new species an Astacidea.

Family Nephropidae Dana, 1852

Remarks: According to Holthuis (1974: 732), "The pattern of the grooves of the carapace is very striking" with several grooves recognized in some or all Nephropidae. The carapace grooves in the new species (i.e., cervical, postcervical, branchiocardiac and inferior; Fig. 3) seem to be a reasonable ground for the inclusion in this family.
Genus Hoploparia McCoy, 1849

Remarks: The material is considered to be a Hoploparia species on the basis of the carapace with small tubercles mostly in the posterior half, and the presence of the cervical, postcervical, branchiocardiac and inferior grooves and the absence of carinae common in other groups, such as Metanephrops Jenkins, 1972, in which most species have the carapace with supraorbital and postorbital carinae. Also, some of the characters used by Tshudy (1993) to define Hoploparia are presence of a long and spinose rostrum; with a postcervical groove well impressed over most of its length; a cervical groove and a branchiocardiac groove usually present. As compared with Hoploparia longimana Sowerby, 1826, the type species of the genus, both species share a carapace posteriorly granulated and an elongated cheliped, and a palm armed with few tubercles. However, the new species has the pleural and tergal regions of the pleon separated with a marked sulcus (smooth in H. longimana). Also, Hoploparia is mostly known from shallow marine Cretaceous deposits (Tshudy \& Sorhannus 2000), which is the case of Lachman Crags Member, where the material studied here was collected.

Hoploparia echinata sp. nov.

Zoobank act: LSID urn:lsid:zoobank.org:act:643B193A3B0F-437D-B447-808FDD6EB8C7

Figures 3a-e, 4, 5

Etymology. From the Latin echinatus, which means spiny, referring to the spinulose characteristic of the legs and third maxillipeds.

Type material. The holotype and the paratype are deposited in the MN, under catalogue numbers MN 10435-I and 10436-I, respectively. The material was not lost in the fire of the MN/UFRJ in 2018 (Kellner 2019).

Type locality. Santa Marta Cove, James Ross Island, Antarctica.

Stratigraphic unit. Santa Marta Formation.

Type age. Upper Cretaceous (Santonian-Campanian).

Diagnosis. Carapace with small tubercles sparsely distributed, mostly on the posterior half; postcervical, intercervical, cervical grooves visible; without branchial, intermediate carina on posterior half of carapace. Third maxillipeds, cheliped and pereopods 2 and 3 ornamented with distinct, short spines on dorsal and ventral margins.

Description. Carapace poorly preserved, represented by an imprint on the matrix, with small tubercles sparsely distributed, mostly on the posterior half; cervical, 

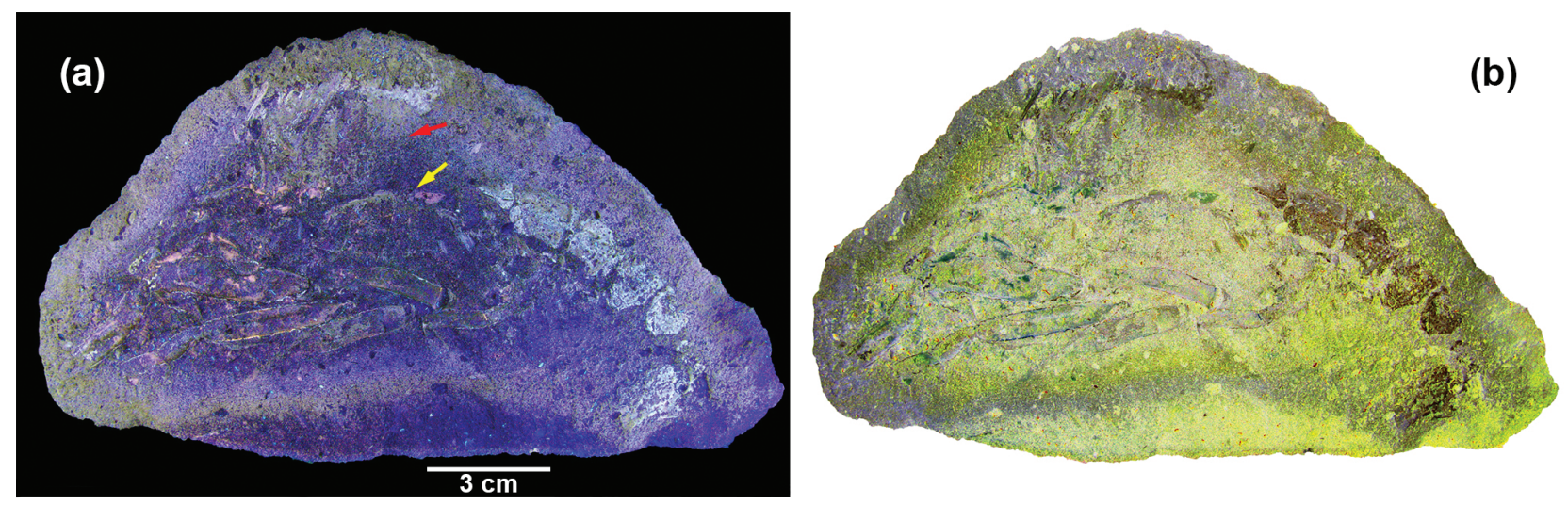

(c)
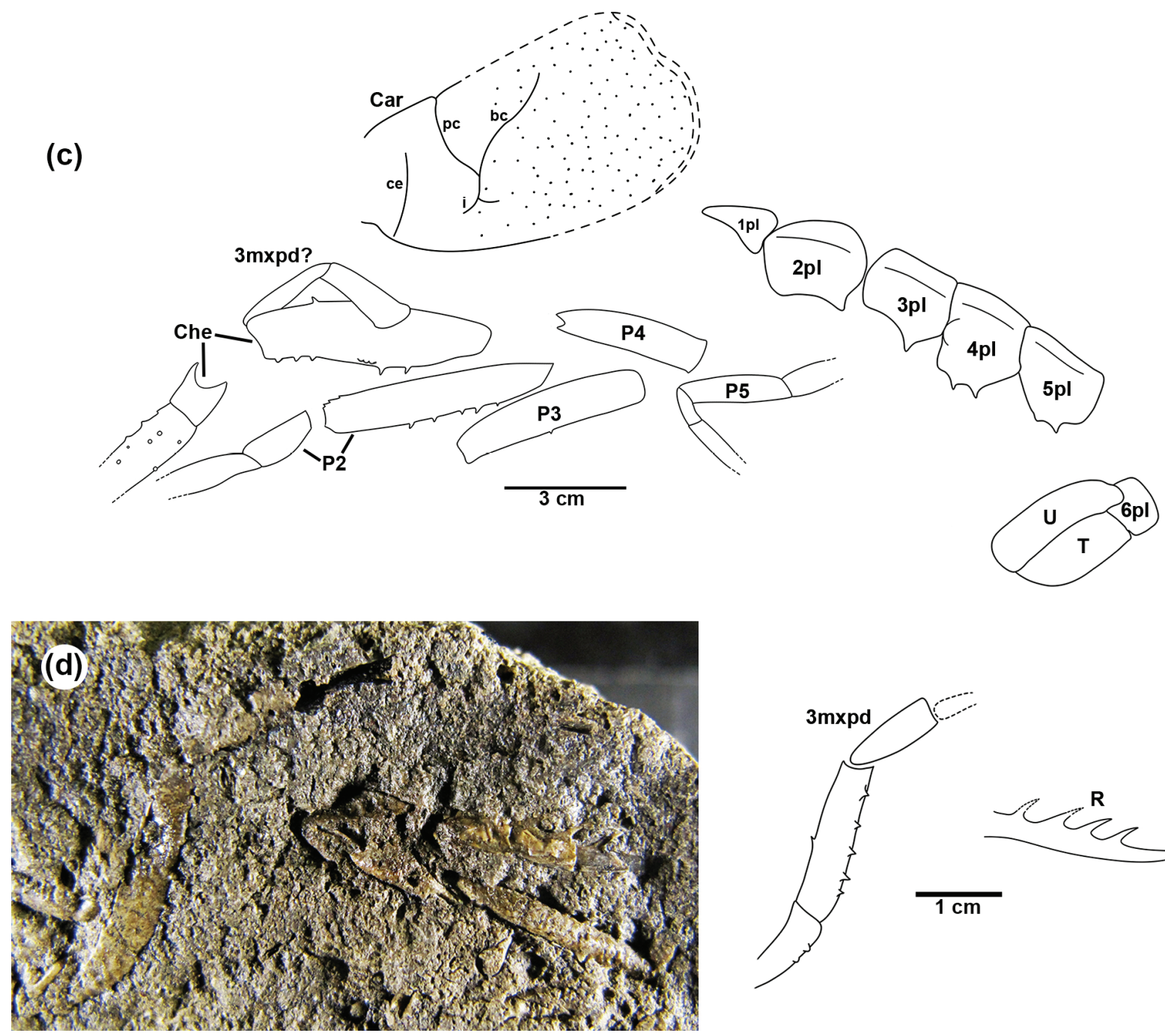

(e)

Fig. 3 (a) Holotype (MN 10435-I) of H. echinata sp. nov. in lateral view under ultraviolet light, specimen dry, uncoated. The red arrow indicates the position of the carapace; the yellow arrow indicates the position of the endophragmal skeleton. (b) Holotype in lateral view with inverted colours. (c) Line drawing of the holotype: carapace, pereopods, pleon, telson and uropods detached. (d) Paratype (MN 10436-I) third maxilliped and rostrum, specimen dry, coated with Paraloid B-72. (e) Line drawing of the third maxilliped and rostrum of the paratype. Abbreviations: Car, carapace; ce, cervical groove; pc, postcervical groove; bc, branchiocardiac groove; i, inferior groove; R, rostrum; Che, cheliped; P2-P5, pereopods 2-5; 3mxpd, third maxilliped; 1 pl to $6 \mathrm{pl}$, first to sixth pleonite; U, uropod; T, telson. 


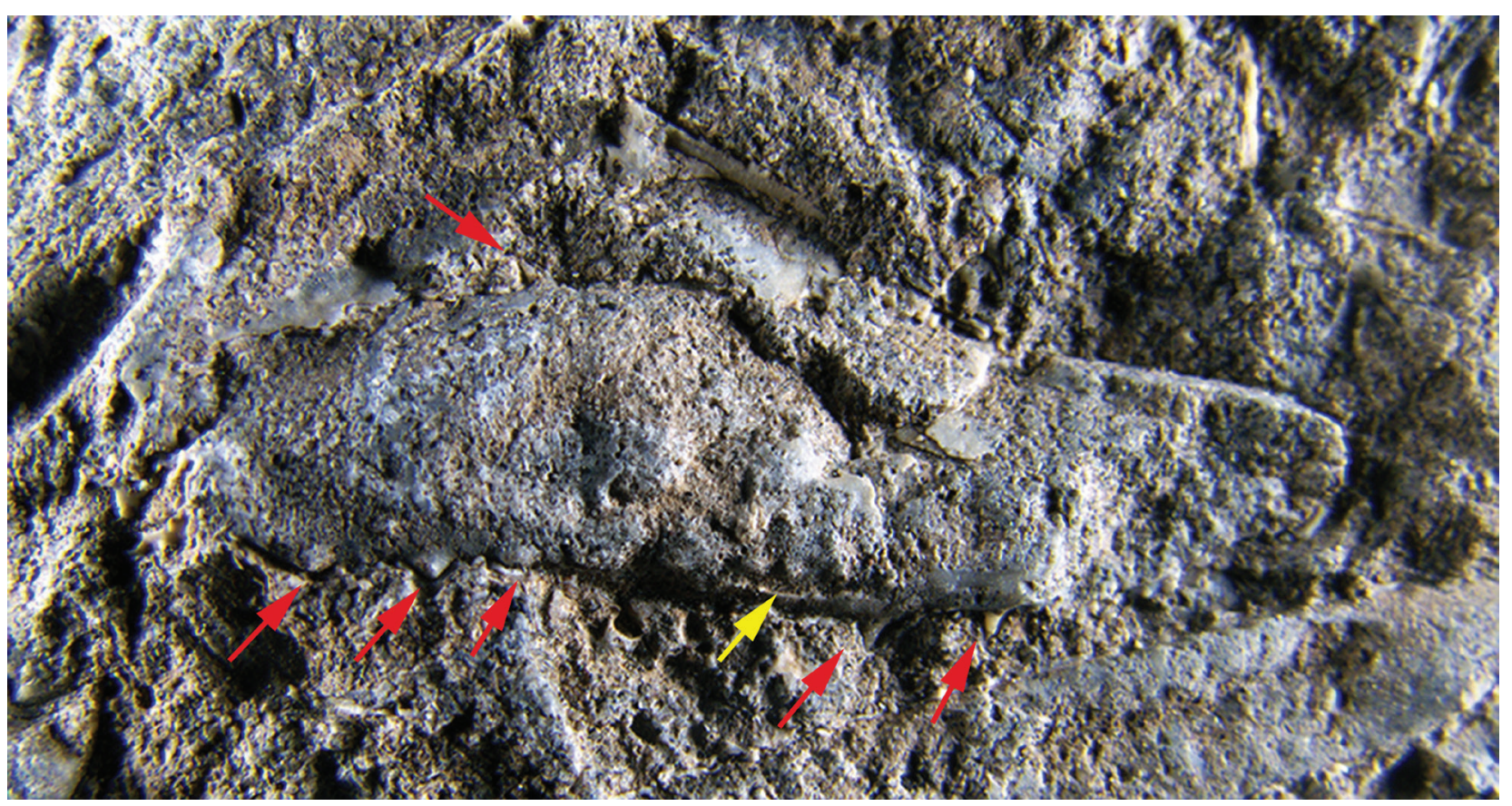

Fig. 4 Detailed view of the merus of the cheliped of $H$. echinata sp. nov. holotype (MN 10435-I). The red arrows show the ventral and a dorsal spine. The yellow arrow shows a line of three ventrolateral tubercles.

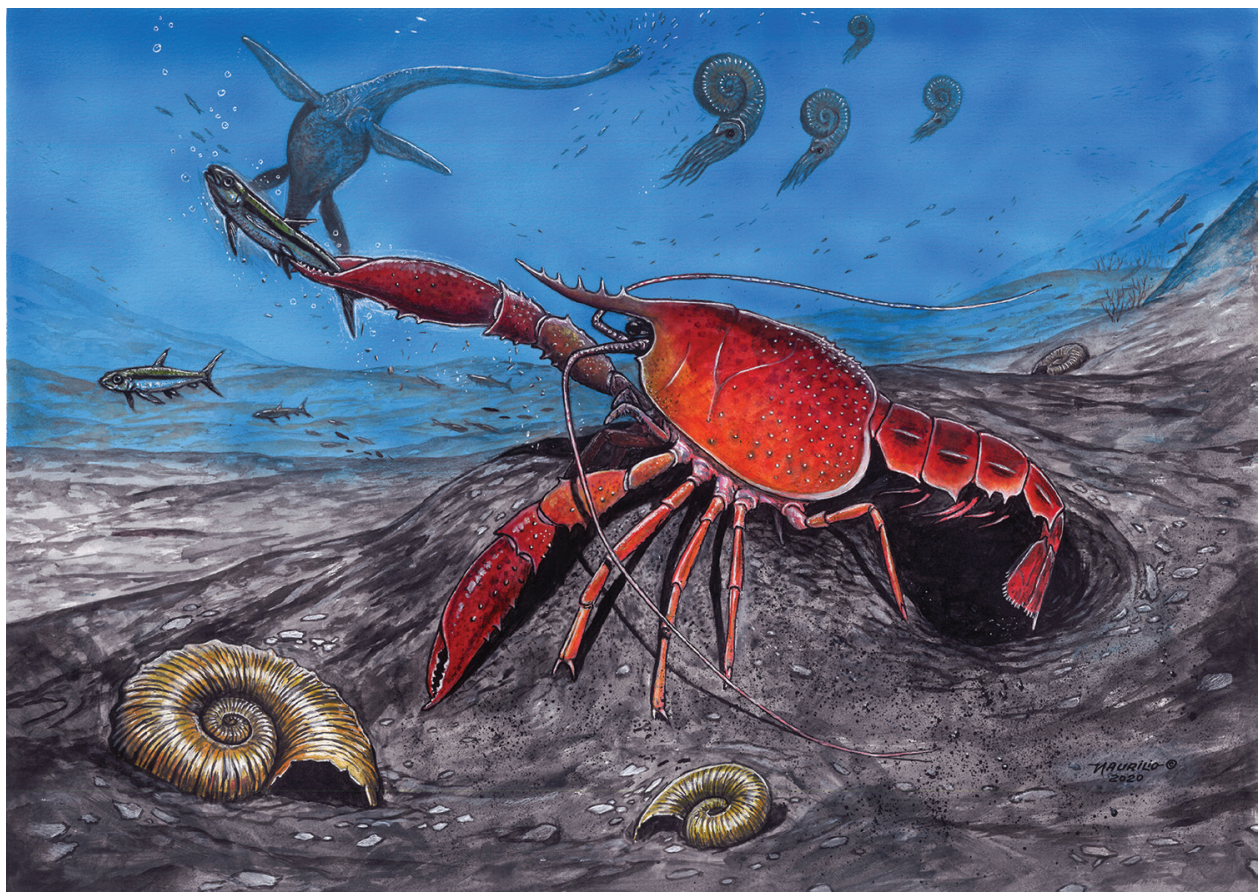

Fig. 5 Reconstruction of $H$. echinata sp. nov. in its palaeoenvironment. Illustration by Maurilio Oliveira (palaeoartist, MN/UFRJ). 
postcervical, branchiocardiac and inferior grooves visible, without branchial, intermediate carina on posterior half of carapace. Margins of the posterior half of the carapace indiscernible from the matrix. Cephalic appendages not preserved. Rostrum fragment (paratype) possible long and at least laterally flattened distally, slightly upward and tapering distally, with, at least, four distinct spines dorsally, smooth ventrally; rostral spines forward directed. Third maxilliped distinctly preserved in paratype, slightly compressed laterally, with ischium, merus and carpus complete, propodus partially preserved, coxa and basis not preserved; ischium with two blunt tubercles ventrally; merus with four-five short, strong spines on ventral margin, one dorsally; carpus smooth. A fragment with two segments in holotype is possibly part of the third maxilliped. First and second maxillipeds not preserved. Cheliped preserved; merus and carpus fully preserved, laterally compressed; palm partially preserved proximally, slightly inflated. Merus with two spines and three strong, blunt tubercles ventrally, one dorsal acute, short spine; merus with additional row of blunt tubercles ventrolaterally; carpus smooth; palm partially preserved with distinct tubercles, sparsely distributed in all surfaces. Pereopods laterally compressed. P2 with merus and carpus preserved, propodus partially preserved; merus with line of five, well-spaced, acute, short spines on ventral margin, dorsal margin with three small projections grouped distally. P3 merus preserved, other articles not preserved, merus with only one acute tubercle on ventral margin medially. P4 with only merus preserved, apparently smooth. P5 with ischium partially preserved, apparently smooth; merus and carpus fully preserved, smooth; propodus partially preserved, smooth. Pleon with six pleonites, all preserved; pleural and tergal regions separated with visible sulcus on second to fifth pleonites; pleonites without spines or tubercles. First pleonite reduced, second slightly longer, third to fifth pleonites of about same size. Second and third pleonites with one posterolateral strong spine; fourth with two distinct spines on lateral margin; fifth pleonite with one blunt tubercle anteriorly, one strong spine posteriorly on lateral margin; sixth pleonite smooth, short. Telson and uropods apparently without ornamentation, uropods only partially preserved.

\section{Discussion}

The holotype material of $H$. echinata sp. nov. consists of a carapace disconnected from pleon and pereopods, with the endophragmal skeleton visible under ultraviolet light. The position of the carapace displaced from the pereon and pleon suggests this could be an exuvia by the typical "lobster open moult" position (Daley \& Drage 2016). The paratype is represented by the third maxilliped, some pereopod fragments and a fragment putatively identified as the distal part of the rostrum. The new species can easily be differentiated from other Hoploparia by the ornamentation of the third maxilliped, merus of the cheliped and pereopods with distinct, acute, short spines on dorsal and ventral margins (in contrast to other Hoploparia, which have smooth third maxillipeds and pereopods, chelipeds ornamented only in the palm and fingers). Despite the great amount of Hoploparia material known, there is no mention of spines or ornamentation in maxillipeds and pereopods in any other species of the genus. In fact, from the more than 60 known species of Hoploparia, only two original descriptions mention the third maxillipeds: Hoploparia catalunica Garassino, Artal \& Pasini, 2009 and Hoploparia miyamotoi Karasawa, 1998, both without ornamentation. Also, Quayle (1987), in the designation of a neotype to Hoploparia gammaroides McCoy, 1849, provided a detailed description and figure of its third maxilliped ornamented with finely punctuation and spaced pores, but no spines.

Compared with its congeners in the austral region, $H$. echinata sp. nov. differs from Hoploparia antarctica Wilckens, 1907 by the gastroorbital, antennal, buccal, urogastric and branchiocardiac grooves apparently absent, which are present in the carapace of $H$. antarctica (Aguirre-Urreta et al. 1991). Hoploparia gazdzickii Feldmann \& Crame, 1998 can be differentiated from the new species by the presence of a straight antennal groove, two rows of spines on the cephalic region and an antennal spine, all absent in H. echinata sp. nov. The new species seems to be morphologically more closely related to H. stokesi (Weller, 1903), from which it can be distinguished by the presence of distinct, acute tubercles and spines on the dorsal and ventral pereopod margins.

Hoploparia is a very speciose genus, especially in Europe, where more than 50 species are known (El-Shazly 2015). For Antarctica, H. echinata sp. nov. is the fourth species described. It is unknown whether the paucity of Hoploparia species found so far in Antarctica is a function of the challenges of carrying out research there or if it reflected the small number of species that lived in this region. In any case, the great morphological variation among species included in the genus Hoploparia makes it a challenge to characterize. This genus forms a paraphyletic group, considered a "wastebasket taxon", default receptacle for taxa excluded from other higher groupings for several authors (e.g., Tshudy \& Sorhannus 2003; Tshudy et al. 2018). Likewise, we observe that there is a high degree of morphological variation in the specimens attributed to H. stokesi, indicating that a revision of the species and of the genus is needed. This would not be an easy task given the number of species in the genus and amount of material from different parts of the world attributed to Hoploparia. 


\section{Acknowledgements}

The team of the PALEOANTAR project wants to thank the NApOc Ary Rongel military group for the logistical support that allowed us to arrive on James Ross Island, Antarctica. The pilots of the HU-1 helicopter squadron safely delivered our personnel, scientific and camping equipment from the ship to the island and back again, in addition to taking the collected samples. The alpinists Edson Vandeira, Ricardo Leizer and Renato Dias ensured the team's physical integrity during excursions on James Ross Island, as well as keeping the camp running during the expedition. We thank the TERRANTAR-Permafrost, Cryosoils and Terrestrial Ecosystems and Climatic Change Studies in Antarctica project team (Carlos Schaeffer, Maiara Daher, Eduardo Senra, Carsten Müller and Lars-Arne Meier) for their partnership in the shared camp and for their collaboration during the field activities.

\section{Funding}

This study was supported by PROANTAR (CNPq no. 407670/2013-442677/2018-9 to AWAK), Conselho Nacional de Desenvolvimento Científico e Tecnológico (CNPq no. 420687/2016-5-313461/2018-0 to AWAK; no. 312360/2018-5 to TR; no. 311715/2017-6 to JMS), Fundação Carlos Chagas Filho de Amparo a Pesquisa do Estado do Rio de Janeiro (FAPERJ no. E-26/202.905/2018 to AWAK) and Coordenação de Aperfeiçoamento de Pessoal de Nível Superior, Brasil, finance code 001 (fellowship no. 88887.169169/2018-00 to WS and grant Proequipamentos no. $775705 / 2012$ to APP).

\section{Disclosure statement}

The authors report no potential conflict of interest.

\section{References}

Aguirre-Urreta M.B., Olivero E.B. \& Medina F.A. 1991. A redescription of a Maastrichtian lobster Hoploparia antarctica Wilckens, 1907 (Crustacea: Decapoda), from Chubut, Argentina. Journal of Paleontology 65, 795-800, doi: 10.1017/S0022336000037781.

Ball H.W. 1960. Upper Cretaceous Decapoda and Serpulidae from James Ross Island, Graham Land. Falkland Islands Dependencies Survey Report 24. London: Her Majesty's Stationery Office.

Carvalho M.A., Ramos R.R.C., Crud M.B., Witovisk L., Kellner A.W.A., Silva H.P., Grillo O.N., Riff D. \& Romano P.S.R. 2013. Palynofacies as indicators of paleoenvironmental changes in a Cretaceous succession from the Larsen Basin, James Ross Island, Antarctica. Sedimentary Geology 295, 53-66, doi: 10.1016/j.sedgeo.2013.08.002.
Clarke A., Aronson R.B., Crame J.A., Gili J.M. \& Blake D.B. 2004. Evolution and diversity of the benthic fauna of the Southern Ocean continental shelf. Antarctic Science 16, 559-568, doi: 10.1017/S0954102004002329.

Crame J.A. 1989. Origins and evolution of the Antarctic biota: an introduction. Geological Society, London, Special Publications 47, 1-8, doi: 10.1144/GSL.SP.1989.047.01.01.

Crame J.A., Francis J.E., Cantrill D.J. \& Pirrie D. 2004. Maastrichtian stratigraphy of Antarctica. Cretaceous Research 25 , 41 1-423, doi: 10.1016/j.cretres.2004.02.002.

Crame J.A., Lomas S.A., Pirrie D. \& Luther A. 1996. Late Cretaceous extinction patterns in Antarctica. Journal of the Geological Society 153, 503-506, doi: 10.1 144/gsjgs.153.4.0503.

Crame J.A., McArthur J.M., Pirrie D. \& Riding J.B. 1999. Strontium isotope correlation of the basal Maastrichtian Stage in Antarctica to the European and US biostratigraphic schemes. Journal of the Geological Society 156, 957-964, doi: 10.1144/gsjgs.156.5.0957.

Crame J.A., Pirrie D., Riding J.B. \& Thomson M.R.A. 1991. Campanian-Maastrichtian (Cretaceous) stratigraphy of the James Ross Island area, Antarctica. Journal of the Geological Society 148, 1125-1140, doi: 10.1144/ gsjgs.148.6.1125.

Daley A.C. \& Drage H.B. 2016. The fossil record of ecdysis, and trends in the moulting behaviour of trilobites. Arthropod Structure O Development 45, 71-96, doi: 10.1016/j. asd.2015.09.004.

Dana J.D. 1852 (preprint of 1854 publication) Conspectus Crustaceorum, $8 \mathrm{c}$. Conspectus of the Crustacea of the exploring expedition under Capt. Wilkes, U.S.N. Macroura. Proceedings of the Academy of Natural Sciences, Philadelphia 6, 6-28.

El-Shazly S.H. 2015. Cretaceous-tertiary Hoploparia species: occurrence, paleobiogeography and predation context. Journal of African Earth Sciences 112, 299-313, doi: 10.1016/j.jafrearsci.2015.09.014.

Feldmann R.M. 1989. Metanephrops jenkinsi n. sp. (Decapoda: Nephropidae) from the Cretaceous and Paleocene of Seymour Island, Antarctica. Journal of Paleontology 63, 64-69, doi: 10.1017/S0022336000040968.

Feldmann R.M. 1990. Decapod crustaceans from James Ross Island, Antarctica. Antarctic Journal of the United States 25, 45-46.

Feldmann R.M. \& Crame J. 1998. The significance of a new nephropid lobster from the Miocene of Antarctica. Palaeontology 41, 807-814.

Feldmann R.M. \& Tshudy D. 1987. Ultrastructure in cuticle from Hoploparia stokesi (Decapoda: Nephropidae) from the Lopez de Bertodano Formation (Late Cretaceous-Paleocene) of Seymour Island, Antarctica. Journal of Paleontology 61, 1194-1203, doi: 10.1017/S0022336000029565.

Feldmann R.M. \& Tshudy D.M. 1989. Evolutionary patterns in macrurous decapod crustaceans from Cretaceous to early Cenozoic rocks of the James Ross Island region, Antarctica. Geological Society, London, Special Publications 47, 183-195, doi: 10.1144/GSL.SP.1989.047.01.14.

Feldmann R.M., Tshudy D.M. \& Thomson M.R.A. 1993. Late Cretaceous and Paleocene decapod crustaceans from 
James Ross Basin, Antarctic Peninsula. Journal of Paleontology 67, Paleontological Society Memoir 28, 1-41, doi: 10.1017/ S0022336000062077.

Hathway B. 2000. Continental rift to back-arc basin: Jurassic-Cretaceous stratigraphical and structural evolution of the Larsen Basin, Antarctic Peninsula. Journal of the Geological Society 157, 417-432, doi: 10.1144/jgs.157.2.417.

Hathway B. \& Riding J.B. 2001. Stratigraphy and age of the lower Cretaceous Pedersen Formation, northern Antarctic Peninsula. Antarctic Science 13, 67-74, doi: 10.1017/ S0954102001000104.

Holthuis L.B. 1974. The lobsters of the superfamily Nephropidae of the Atlantic Ocean (Crustacea: Decapoda). Bulletin of Marine Science 24, 723-884.

Holthuis L.B. 1991. FAO species catalog. Vol. 13. Marine lobsters of the world. An annotated and illustrated catalogue of species of interest to fisheries known to date. Rome: Food and Agriculture Organization of the United Nations.

Kellner A.W.A. 1996. Reinterpretation of a remarkably well preserved pterosaur soft tissue from the early Cretaceous of Brazil. Journal of Vertebrate Paleontology 16, 718-722, doi: 10.1080/02724634.1996.10011360.

Kellner A.W.A. 2019. A reconstrução do Museu Nacional: bom para o Rio, bom para o Brasil! (The reconstruction of the National Museum: good for Rio, good for Brazil!) Ciência e Cultura 71(3), 4-5, doi: 10.21800/2317-6660201 9000300002.

Kellner A.W.A., Rodrigues T., Costa F.R., Weinschütz L.C., Figueiredo R.G., Souza G.A. \& Sayão J.M. 2019. Pterodactyloid pterosaur bones from Cretaceous deposits of the Antarctic Peninsula. Anais da Academia Brasileira de Ciências 91 (Suppl. 2), e20191300, doi: 10.1590/0001-3765201920191300.

Kellner A.W.A., Simões T., Riff D., Grillo O., Romano P., Silva H.P., Ramos R., Carvalho M., Sayão J.M., Oliveira G. \& Rodrigues T. 2011. The oldest plesiosaur (Reptilia, Sauropterygia) from Antarctica. Polar Research 30, article no. 7265, doi: 10.3402/polar.v30i0.7265

Latreille P.A. 1802. Histoire naturelle, générale et particulière des Crustacés et des Insectes. Ouvrage faisant suite à l'histoire naturelle générale et particulière, composée par Leclerc de Buffon, et rédigée par C.S. Sonnini, membre de plusieurs sociétés savantes. Familles naturelles des genres. Vol. 3. (Natural, general and particular history of crustaceans and insects. Book following general and particular natural history, composed by Leclerc de Buffon, and written by C.S. Sonnini, member of several learned societies. Natural families of genera. Vol. 3.) Paris: F. DuFart.

Macdonald J.A., Montgomery J.C. \& Wells R.M.G. 1988. Comparative physiology of Antarctic fishes. In J.H.S. Blaxter \& A.J. Southward (eds.): Advances in marine biology. Vol. 24. Pp. 321-388. London: Academic Press.

Marenssi S.A., Salani F.M. \& Santillana S.N. 2001. Geología de cabo Lamb, isla Vega, Antártida. (Geology of Cape Lamb, Vega Island, Antarctica.) Contribuición Científica del Instituto Antártico Argentino 530. Buenos Aires: Argentine Antarctic Institute.

McCoy F. 1849. XIX. On the classification of some British Fossil Crustacea, with notices of new forms in the University Collection at Cambridge. Annals and Magazine of Natural History 4, 161-179, doi: 10.1080/03745486009494810.
Olivero E.B. 2012. Sedimentary cycles, ammonite diversity and palaeoenvironmental changes in the Upper Cretaceous Marambio Group, Antarctica. Cretaceous Research 34, 348-366, doi: 10.1016/j.cretres.2011.11.015.

Olivero E.B. \& Medina F.A. 2000. Patterns of Late Cretaceous ammonite biogeography in southern high latitudes: the family Kossmaticeratidae in Antarctica. Cretaceous Research 21, 269-279, doi: 10.1006/cres.1999.0192.

Olivero E.B., Scasso R.A. \& Rinaldi C.A. 1986. Revision del Grupo Marambio en la Isla James Ross, Antártida. (Revision of the Marambio Group on James Ross Island, Antarctica.) Instituto Antártico Argentino, Contribución 331. Buenos Aires: Argentine Antarctic Institute.

Quayle W.J. 1987. English Eocene Crustacea (lobsters and stomatopod). Palaeontology 30, 581-612.

Riding J.B. \& Crame J.A. 2002. Aptian to Coniacian (early-Late Cretaceous) palynostratigraphy of the Gustav Group, James Ross Basin, Antarctica. Cretaceous Research 23, 739-760, doi: 10.1006/cres.2002.1024.

Scasso R.A., Olivero E.B. \& Buatois L.A. 1991. Lithofacies, biofacies, and ichnoassemblage evolution of a shallow submarine volcaniclastic fan-shelf depositional system (Upper Cretaceous, James Ross Island, Antarctica). Journal of South American Earth Sciences 4, 239-260, doi: 10.1016/0895-9811(91)90034-I.

Schweitzer C.E., Feldmann R.M., Garassino A., Karasawa H. \& Schweigert G. 2010. Systematic list of fossil decapod crustacean species. Crustaceana Monographs 10. Leiden: Brill. doi: 10.1163/ej.9789004178915.i-222.

Tshudy D. 1993. Taxonomy and evolution of the clawed lobster families Chilenophoberidae and Nephropidae. PhD dissertation, Kent State University.

Tshudy D., Hy̌̌ný M., Dulai A. \& Jagt J.W. 2018. Appraisal of the fossil record of Homarus (nephropid lobster), with description of a new species from the upper Oligocene of Hungary and remarks on the status of Hoploparia. Journal of Paleontology 92, 170-182, doi: 10.1017/ jpa.2017.65.

Tshudy D. \& Sorhannus U.L.F. 2000. Pectinate claws in decapod crustaceans: convergence in four lineages. Journal of Paleontology 74, 474-486, doi: 10.1017/S00223360000 31735.

Tshudy D. \& Sorhannus U.L.F. 2003. Hoploparia, the bestknown fossil clawed lobster (Family Nephropidae), is a "wastebasket" genus. Journal of Crustacean Biology 23, 700-711, doi: 10.1651/C-2353.

Weller S. 1903. The stokes collection of Antarctic fossils. The Journal of Geology 11, 413-419, doi: 10.1086/621086.

Wilckens O. 1907. Die Lamellibranchiaten, Gastropoden etc. der oberen Kreide Südpatagoniens. (The Lamellibranchian, gastropods etc. of the upper Cretaceous in southern Patagonia.) Berichte der Naturforschenden Gesellschaft zu Freiburg 15, 97-166.

Zhang X., Jiang S., Cheng X. \& Wang X. 2019. New material of Sinopterus (Pterosauria, Tapejaridae) from the early Cretaceous Jehol Biota of China. Anais da Academia Brasileira de Ciências 91, e20180756, doi: 10.1590/0001-3765201 920180756. 